\title{
The Effect of Mobile Social Networking as a Supplementary Strategy on EFL Learners' Writing Ability
}

Sedigheh Talakoub*

Department of English Language, Bandar Abbas Branch, Islamic Azad University, Bandar Abbas, Iran

Corresponding Author: Sedigheh Talakoub, E-mail: Talakoubsedigheh@gmail.com

\section{ARTICLE INFO}

\section{Article history}

Received: November 14, 2017

Accepted: January 10, 2018

Published: March 01, 2018

Volume: 7 Issue: 2

Advance access: February 2018

Conflicts of interest: None

Funding: None

\begin{abstract}
The popularity of mobile learning and social networking sites has encouraged second language instructors to integrate these technologies into learners' curriculum. In this study, the learners were supposed to practice in an online jigsaw writing as an extra-curricular activity. They used their imagination and creativity to depict their thoughts using their previous knowledge. The current research had both a qualitative and quantitative phases. From the quantitative perspective, the effectiveness of mobile social networking on EFL learners' writing ability was examined statistically. In doing so, 60 EFL learners were divided into the experimental and control groups. The learners of the experimental group were also assigned into three virtual groups in which they could help each other to write a piece of writing on pre-determined topics during twelve sessions. Running the t-test indicated that the students in the experimental group could significantly outperform their counterparts in the post-test. Therefore, it could be claimed that mobile social networking as a supplementary strategy had positive effects on EFL learners' writing ability. In the qualitative phase of the study, a semi-structured interview was conducted in order to explore learners' attitudes and beliefs about the experiment they had. The responses to the semi-structured interview also revealed that the learners had positive attitudes towards this online supplementary technology-supported writing. The pedagogical implications of the study were discussed and further suggestions were put forward.
\end{abstract}

Key words: Social Networking, Mobile Social Networking, Collaborative Writing

\section{INTRODUCTION}

Writing is a formal means of communicating which has been a labored skill for even most native people of a language to master (Faghih \& Rahimpour, 2009). It can be assumed as a torment for learners (Parker, 1993). It is apparent that strong writing skills can be a guarantee of enhancing students' chances for their success (Alexander, 2008). The difficulty in acquiring writing skill lies not only in generating and organizing ideas but also in translating these ideas into a readable text (Richards \& Renandya, 2002). Raimes (1983) also declared that writing makes the learners experience a new way of learning. While writing a text, learners use the knowledge of the language they have already gained; vocabulary and new and old information. Byrne (1979) also believed that "The act of writing helps in strengthening the vocabulary and grammatical structures to which the learners have been exposed to" (p. 7).

Khabiri and Tonekaboni (2009) also showed that "foreign language learners, especially those who want to continue their education in academic contexts, usually find writing a highly difficult and challenging task. Part of the difficu ty lies in the fact that most students receive minimal or no instruction in learning how to write" (p. 54). It is necessary for L2 writers to pay attention to higher level skills of planning and organizing as well as lower level skills of spelling, punctuation, word choice, and so on. Writing involves highly complex skills.

On the other hand, the advocators of social constructivism, including Vygotsky (1978) believed that learning occurs as a result of social interactions. These notions shifted both teachers' and researchers' attention to a new method of writing called collaborative writing. Collaborative writing (CW) provides an outstanding platform for learners to write as a part of a community and use each other for support and guidance (Kessler, Bikowski, \& Boggs, 2012). The most defining feature of collaborative writing is social interaction which leads to high level of engagement among members (Dale, 1997).

Later, with the advent of the internet, the focus of the studies shifted to computer-mediated communication (CMC) in writing (e.g. email, blogs, wikis, online discussion boards, etc.). Social networking sites are one of the CMC applications which facilitate collaboration in a virtual community. This function has led the emergence of a new trend in writing called "online collaborative writing". The use of 
social networking websites move the learning from beyond the classroom and its formal setting and give learners the ability to mix formal and informal language learning (Curcher, 2009).

With regard to the pedagogical setting in Iran where learners do not enjoy an adequate amount of exposure to the target language, with the inevitable importance of writing skill especially for those who need to participate in international exams and conferences, any effort of investigation which can facilitate gaining this skill for language learners and help them make connections between new technologies and learning in this area seem to be of utmost importance. Most of the research on online collaborative writing is focused on asynchronous collaboration. Asynchronous collaboration does not foster a sense of community among members of a group and more importantly, it is impossible for researchers to monitor entire learners' co-authoring. Hence, this study provides a feasible mode by which participants work interactively with each other throughout the process of a jigsaw writing project. Designing extra-curricular activities using technology in parallel to traditional classes may mitigate monotonous learning.

\section{Research Questions}

Q1: Does the implementation of mobile social networking as a supplementary strategy have any significant effect on intermediate EFL learners' writing ability?

Q2: What are learners' attitudes toward social networking supported writing?

\section{Research Hypothesis}

On the basis of the above-mentioned research questions, there is only this quantitative null hypothesis is formulated:

$\mathrm{H}_{0} 1$ : The implementation of mobile social networking as a supplementary strategy has no effect on intermediate EFL learners' writing ability.

\section{REVIEW OF LITERATURE}

\section{Collaborative Writing}

In the $1980 \mathrm{~s}$, collaborative learning gained much popularity due to its differing approaches in writing. Since then, many instructors of writing became advocators of collaboration in the process of teaching and learning. According to Ede and Lunsford (1990), collaborative writing refers to any writing done in collaboration with one or more persons. In this way, writing instruction shifted from a product-oriented approach to process-oriented approach. It is apparent that sharing different views in such a platform provides learners an opportunity to broaden horizons when they are creating a written form. Palincsar (1987) emphasizes reciprocal teaching in which both students and teachers collaborate in creating a text or document.

The theoretical basis is largely based on the work of Vygotsky (1978) who emphasized the role of social interaction. Language learning always occurs in the process of social interaction. Studies proved that valuable information which is obtained as a consequence of social interactions can be more efficient than one from writing products (Masoodian $\&$ Luz, 2001). Collaborative writing focuses on a social interaction process where learners contribute their particular ideas or expertise, take account others' perspectives to complete a writing task (Speck, Johnson, Dice, \& Heaton, 1999).

Due to its inimitable features, collaborative writing has many potential benefits such as enhancing learning (Trimbur, 1985); socializing through establishing relationships between individuals (LeFevre, 1987); constructing interpersonal skills (Rice \& Huguley, 1994); promoting motivation (Brown, 2001; Mellati \& Khademi, 2014); improving the quality of writing (Beck, 1993); raising writing performance (Beck, 1993); sharing knowledge and diverse views (Ede \& Lunsford, 1990); promoting critical reading and writing among learners (Nystrand \& Brandt, 1989; Fahim, Miri, \& Najafi, 2014); developing critical thinking, reducing anxiety, and providing feedback (Gokhale, 1995).

Saunders (1989) classified four types of collaborative writing, namely co-writing, co-publishing, co-responding and helping. In co-writing, peers collaborate on every task. Co-publishing refers to the collaborative situation in which peers co-publish a collaborative task based on individual texts. In co-responding writing, peers interact only during a revision process. Writers voluntarily help each other during the writing process when they employ helping collaborative writing.

On the other hand, Louth, McAllister, and McAllister (1993) also proposed another division for this category: interactive writing and group writing. In interactive writing, group members interact with each other during each stage of the writing process. However, individuals are ultimately responsible for their own task. In group writing, group members also interact during the various stages of the writing process, but they equally take responsibility for the quality of the final product

Many studies conducted in this field support the notion that learners would be more effective when they work together than when they are isolated. Indeed, when learners collaborate and engage in the same task, they can fortify their team-work skills. In such setting, anxiety can be reduced, self-esteem can be increased, learners' involvement can be fostered, and a positive attitude towards the learning can be developed. That is why Dornyei (2001) advocates collaborative environment. Dynamicity plays an important role in effective collaboration, while the competitive structured group can be a hindrance (Johnson, Johnson, \& Smith, 2007).

\section{Technology Assisted Collaborative Writing}

The related literature review reveals that technology has influenced the writing process and practices in many ways. The transition from pen to word processing is one of the consequences of exploiting technology in writing process (Pennington, 1991). Due to the spell-check function, word processing can raise the quality of writing (Santangelo \& Olinghouse, 2009). 
Later, with the advent of the internet, the focus of the studies shifted to computer-mediated communication (CMC) in writing (e.g. email, blogs, wikis, online discussion boards, etc.). CMC can take place in two modes: synchronous mode, in which communication develops in real time simultaneously, and asynchronous mode, in which communication occurs with delay (Warschauer, 1999). CMC tools provide learners with a non-threatening environment in which they can practice writing (Colomb \& Simutis, 1996). Pellettieri (1999) believed that CMC promotes grammatical development. Furthermore, it facilitates online collaborative language learning (Warschauer, 1997) and whereby a new strand of collaborative writing named online collaborative writing emerged.

Online interaction environments which involve an active construction of knowledge can be potentially used as a powerful tool for collaborative learning and group communication (Nguyen, 2008). Online collaborative learning is identified as a strategy that provides students with high level of interaction (Johnson \& Johnson, 2004). Asynchronous networking tools offer ample chance for learners to organize, compose and revise content asynchronously (Lee, 2010), although some networking tools allow writers to discuss and share their ideas synchronously. Text chats in a collaborative environment provide an avenue for learners to reflect and negotiate meanings with their peers (O’Sullivan, Mulligan, \& Dooley, 2007).

Technology-assisted collaborative writing enjoys many potential benefits such as promoting planning in writing (Dale, 1997); producing argumentative writing (Wells \& Chang-Wells, 1992); decreasing writing anxiety or writing apprehension (Johnson, Johnson, \& Smith, 1991), empowering autonomy and motivation (Warschauer, Turbee, \& Roberts, 1996); providing and receiving timely feedback from peers (Storch, 2005; Webb, 1989). The feedback addresses learners' misconceptions and linguistic problems. While the students co-construct and co-edit, they are exposed to linguistic input as well as vocabulary or sentence structures (Lee, 2002).

Introducing new technologies such as mobile phones and social networking increase the number of projects pertaining to online collaborative writing. These projects provide learners opportunities by which they can more easily work in groups. Kessler (2009) cited that the amount of teacher intervention and learners' autonomy influence the results of online collaborative writing projects. Undoubtedly, Teachers' pedagogical beliefs and experiences and familiarity with these technologies play an indispensable role and affect the amount of learners' success. According to Rahimi and Yadollahi (2010), better integration of technology in EFL classrooms entails a lower technology anxiety; old teachers are usually more hesitant to incorporate technology into their classes because of the higher levels of anxiety. Certainly, technology by itself does not guarantee a better education. The task and activities which are mediated by technology have also greater effects on enhancing learning.

The role of the individual writer in a collaborative writing project is not yet understood. Simultaneous writing through social networking technology is likely to grow in the future. Of interest to researchers is to uncover how these abilities that technologies afford may affect the process of collaborative writing itself. As can be the above studies provide no objective insight into the effect of mobile social networking as a supplementary strategy on EFL learners' writing and there is no accurate picture of learners' attitudes toward social networking supported writing. The purpose of this study is then to examine closely and objectively the above-mentioned objectives and shed light on learners' language learning process, especially writing ability.

\section{METHODOLOGY}

\section{Research Design}

This study employed both quantitative and qualitative approach to gain in-depth information useful for the study. First, the researcher decided to use the quasi-experimental method which is quantitative in nature to answer the first research question of the study and then it has attempted to find an appropriate answer for the second research question qualitatively, using an interview.

\section{Participants}

The participants of this study were 60 students of the intermediate level in a private language institute in Esfahan and they were studying American English File three. All of them were female learners who were studying English as a foreign language and their native language was Persian. The students were divided into the experimental and control groups. There was no random selection of the subjects because of the already existing classes. The age range of learners was between14-20. They almost had an acceptable command of English.

\section{Instrumentation}

- The Preliminary English Test (PET) as a pre-test before the beginning of the treatment;

- The Preliminary English Test (PET) as a post-test after finishing the treatment

- A semi-structured interview to reveal the learners' perceptions of such collaborative experience they had during the treatment.

\section{Procedure}

Assigning the participants to experimental and control group, PET writing test was run to all participants as a pretest to investigate participants' writing ability and also to check that there were no notable differences between them. After students' level was determined and the teacher became sure that the experimental and control groups had the same proficiency level in each grade, the treatment was started. Students in the control group benefited the same teaching method as those in the experimental group that is the teacher taught grammatical points, rhetorical fi ures cohesion, and coherences as well as texts organization in the class. 
To overcome social loafing, 30 participants in the experimental group were divided into three groups of ten that helped the groups to become more active in accomplishing the writing task. The instructor formed three telegram groups and asked the participants to join their own determined group. This application enables learners to experience simultaneous writing. Furthermore, it records writing process as a "history" which allows the teacher and learners to retrieve written texts. Moreover, students' activities within their team could be observed and analyzed by the researcher in order to determine to what degree students participated in the collaborative writing tasks. The whole team could plan and write a document together but they left the revision to be carried out by a selected group member.

Topics for learners were selected considering the $\mathrm{i}+1$ input Krashen (1985). In doing so, in each treatment session, two or three topics were introduced as the proposed topics, so that the participants experience brainstorming in selecting the more suitable topic for "the day discussion". Twelve topics (appearance and personality, clothing, family, food, shopping, your last trip, making friends, a dream house, a dream vacation, keeping in shape, marriage, your city) were selected during twelve sessions of the treatment (each session was about one and a half-hour). These subjects were all curricula-related.

When they managed to reach consensus on the topic, the participants got involved in group work where the teacher started with one or more sentences regarding "the topic of the day" and the participants each added two or more sentences to it and thus the story evolved. The imagination of learners could help the story to be completed in a way that none of them had already thought about it. Such jigsaw writing task can stimulate learners' creativity and promote their English use. The experimental participants who had been engaged via Telegram group were asked to post their sentences in a pre-determined turn to avoid confusion. Learners were not allowed to interrupt their peers' semi-finished sentences, but rather they had to allow each other to share their own ideas and refine their peers' ideas by adding information or correcting mistakes and even clarifying linguistic misconceptions which finally led to a complete story. It is noteworthy that the teacher was adopting the stance of a facilitator of knowledge in this learner-oriented project. She attended the discussions but contributed minimally because she wanted the participants to perform the task independently. She did not want them to be constantly guided because it would reduce their collaboration. Learners in the control group were asked to write on the same topic at home, too.

By the end of the 12-session treatment, a post test was conducted. The participants were again asked to participate in a sample PET writing test. The exams were graded by two people; the teacher and an external rater to heighten the reliability. They both finally had to reach consensus on the final grades. The results of the pre-test and post-test were statistically analyzed by running an independent t-test using SPSS 22 to examine the efficacy of the treatment

Just when the treatment was finished, an online interview was conducted with the participants of the experimental group. This type of interview as Kumar (2005) mentioned, aims to ensure that interviewees answer exactly the same questions. The interview helped the researcher to reflect the participants' attitudes toward social networking supported writing, the experiences they had during the treatment course and subsequently, find an adequate answer to the second research question; to disclose the amount of the learners' perception of collaborative writing in such virtual environment. For this purpose, the verbatim transcriptions of the interviews were prepared and then summarized. Obtaining precise results entailed categorizing and sorting interviewees' opinions thematically.

\section{Data Analysis}

To investigate the effect of mobile social networking as a supplementary strategy on EFL learners' writing ability in the light of collaboration, an independent t-test was run using the SPSS, version 22. Since this research contains mobile social networking as independent variable and writing ability as a dependent variable, just t-test was used for comparing participants' mean scores of two groups. The results of the pre- tests (i.e. the PET writing tests) and the post-test (on the basis of the administered texts) were statistically analyzed by running a t-test to examine whether or not two groups have different mean values regarding the effect of mobile social networking on their writing ability in the light of collaboration. It was, in fact, necessary to examine the differences between the means to decide whether they are likely to happen by chance alone, or they may be ascribed to the treatment effect (Hatch \& Farhady, 1982).

To increase the reliability of the results, the estimate of inter-rater reliability was necessary. Therefore, exams were double-scored; by the teacher and an external expert rater. PET scoring procedures were explained to the external rater, and she practiced scoring few essays before scoring the whole sample. In scoring the sample essays, both the teacher and the external rater followed the same scoring procedure. The marks given by both raters for each essay in the sample were then correlated.

Finally, a five question interview was also conducted at the end of the experiment to gather students' perceptions of such online collaborative writing in parallel to their traditional classes to boost their writing ability. The researcher prepared the verbatim transcriptions of the interviews. Transcription of the data was imperative to the dependability of analysis. Participants' responses were first summarized. Obtaining precise results entailed categorizing and sorting interviewees' opinions thematically. As Uysal (2010) stated, the reliability increases through double-rating practice, after the researcher analyzed the interview transcripts, an experienced English instructor who had a Master degree in TEFL was invited to evaluate all of the patterns and themes that the researcher identified from the transcripts in order to prevent influences from analytical biases. In this study, the results of the evaluation showed that there was a consistency between the two evaluators, which showed that the result was reliable. 


\section{RESULTS}

\section{Quantitative Phase}

Due to the assignment of the already existing groups to the experimental and control groups, it was required to check the normality of distribution of dependent variable (writing proficiency). Hatch and Lazarton (1991) stated that comparing the mean and standard deviation of two or more groups entails the normality of distribution. To check this assumption, the Kolmogorov-Smirnov test was utilized. This test tries to determine if data sets differ significantl. The null hypothesis for the Kolmogorov-Smirnov test is both samples come from a population with the same distribution. Table 1 shows the result of K-S test.

Given the p-values $(0.085,0.358,0.642,0.579)$ which were all more than the Alpha value; $(\mathrm{P}>.05)$, we cannot reject the null hypothesis. Therefore, the assumption of normality of distribution has been observed.

In order to check the learners' homogeneity in the control and experimental groups, a Preliminary English Test (PET) was used. Students' performance on control and experimental groups was compared by running an Independent Samples Test which determines whether there is a statistically significant difference between the means in two unrelated groups; the experimental group and the control one. The null hypothesis for the Independent Samples Test is that the population means from the two unrelated groups are equal.

With the $\mathrm{t}(-.942)$, df (58), and the Sig. two-tailed (0.35) which was greater than our Alpha value $(.05)$, it can be claimed that the groups were not significantly different from each other and the null hypothesis was not rejected. According to the results shown in Table 2, the homogeneity was confirmed. On the other hand, in the Levene's Test of Equality of Error Variances, the Sig. (0.68) which was greater than our Alpha value (.05) revealed the equality of variances.

In addition, the Paired Sample Test was run in order to compare each learner's pre-test and post-test in both control group and experimental group to check the students' progress at the end of the course. The null hypothesis for the Paired Sample Test is that the scores of learners before and after the course is equal. Since the Sig. is significantly less than the Alpha value (.05), the null hypothesis was rejected. The results of Table 3 showed the improvement of learners' writing ability in both groups. Learners' improvement, especially the improvement of the learners of the control group may be the result of traditional classes.

Assuring the homogeneity of the students in the experimental and control groups, to check the effect of the treatment, an Independent Sample Test was carried out to compare the mean scores of the two groups on the post test. The results of the analysis have been presented in Table 4. With the $\mathrm{t}(-7.71), \mathrm{df}(58)$, and Sig. two-tailed (.000) which is significantly less than our Alpha value (.05), it can be claimed that due to the use of mobile social networking in the experimental group, their writing ability has been improved in comparison with the students in the control group.

Table 1. Kolmogorov-Smirnov test to show normality of the distribution of the data

\begin{tabular}{lcccc}
\hline & Pre-test control & Pre-test exper & Post-test control & Post-test exper \\
\hline $\mathrm{N}$ & 30 & 30 & 30 & 30 \\
Normal parameters ${ }^{\mathrm{a}, \mathrm{b}}$ & & & & 30.93 \\
$\quad$ Mean & 27.20 & 27.70 & 1.760 & 35.00 \\
$\quad$ Standard deviation & 2.340 & 1.725 & & 2.289 \\
Most extreme differences & & & 0.135 & 0.142 \\
Absolute & 0.229 & 0.169 & 0.135 & 0.142 \\
Positive & 0.229 & 0.131 & -0.094 & -0.095 \\
Negative & -0.118 & -0.169 & 0.741 & 0.779 \\
Kolmogorov-Smirnov Z & 1.256 & 0.926 & 0.642 & 0.579 \\
Asymp. Sig. (2-tailed) & 0.085 & 0.358 & & \\
\hline
\end{tabular}

Table 2. Students' performance on pre-test

\begin{tabular}{|c|c|c|c|c|c|c|c|c|c|}
\hline & \multicolumn{2}{|c|}{$\begin{array}{l}\text { Levene's test } \\
\text { for equality } \\
\text { of variances }\end{array}$} & \multicolumn{7}{|c|}{ t-test for equality of means } \\
\hline & \multirow[t]{2}{*}{$\mathbf{F}$} & \multirow[t]{2}{*}{ Sig. } & \multirow[t]{2}{*}{$\mathbf{t}$} & \multirow[t]{2}{*}{ df } & \multirow[t]{2}{*}{$\begin{array}{l}\text { Sig. } \\
\text { (2-tailed) }\end{array}$} & \multirow[t]{2}{*}{$\begin{array}{l}\text { Mean } \\
\text { difference }\end{array}$} & \multirow[t]{2}{*}{$\begin{array}{l}\text { Standard } \\
\text { error } \\
\text { difference }\end{array}$} & \multicolumn{2}{|c|}{$\begin{array}{l}95 \% \text { confidenc } \\
\text { interval of the } \\
\text { difference }\end{array}$} \\
\hline & & & & & & & & Lower & Upper \\
\hline \multicolumn{10}{|l|}{ Score } \\
\hline Equal variances assumed & 3.453 & 0.068 & -0.942 & 58 & 0.350 & -0.500 & 0.531 & -1.562 & 0.562 \\
\hline Equal variances not assumed & & & -0.942 & 53.334 & 0.350 & -0.500 & 0.531 & -1.564 & 0.564 \\
\hline
\end{tabular}


Table 3. Students' performance on Pre-test

\begin{tabular}{|c|c|c|c|c|c|c|c|c|}
\hline & \multicolumn{5}{|c|}{ Paired differences } & \multirow[t]{3}{*}{$\mathbf{t}$} & \multirow[t]{3}{*}{ df } & \multirow{3}{*}{$\begin{array}{c}\text { Sig. } \\
\text { (2-tailed) }\end{array}$} \\
\hline & \multirow[t]{2}{*}{ Mean } & \multirow[t]{2}{*}{$\begin{array}{l}\text { Standard } \\
\text { deviation }\end{array}$} & \multirow[t]{2}{*}{$\begin{array}{l}\text { Standard } \\
\text { error } \\
\text { mean }\end{array}$} & \multicolumn{2}{|c|}{$\begin{array}{l}95 \% \text { confidence } \\
\text { interval of the } \\
\text { difference }\end{array}$} & & & \\
\hline & & & & Lower & Upper & & & \\
\hline \multicolumn{9}{|l|}{ Pair 1} \\
\hline Pre-test control - post-test control & -3.733 & 2.703 & 0.493 & -4.743 & -2.724 & -7.565 & 29 & 0.000 \\
\hline \multicolumn{9}{|l|}{ Pair 2} \\
\hline Pre-test exper - post-test exper & -7.300 & 3.019 & 0.551 & -8.427 & -6.173 & -13.244 & 29 & 0.000 \\
\hline
\end{tabular}

Table 4. Comparing Learners' mean scores on Post-test

\begin{tabular}{|c|c|c|c|c|c|c|c|c|c|}
\hline & \multicolumn{2}{|c|}{$\begin{array}{l}\text { Levene's test } \\
\text { for equality } \\
\text { of variances }\end{array}$} & \multicolumn{7}{|c|}{ t-test for equality of means } \\
\hline & \multirow[t]{2}{*}{$\mathbf{F}$} & \multirow[t]{2}{*}{ Sig } & \multirow[t]{2}{*}{$\mathbf{t}$} & \multirow[t]{2}{*}{ df } & \multirow[t]{2}{*}{$\begin{array}{c}\text { Sig. } \\
\text { (2-tailed) }\end{array}$} & \multirow[t]{2}{*}{$\begin{array}{c}\text { Mean } \\
\text { difference }\end{array}$} & \multirow[t]{2}{*}{$\begin{array}{l}\text { Standard } \\
\text { error } \\
\text { difference }\end{array}$} & \multicolumn{2}{|c|}{$\begin{array}{c}95 \% \text { confidence } \\
\text { interval of the } \\
\text { difference }\end{array}$} \\
\hline & & & & & & & & Lower & Upper \\
\hline \multicolumn{10}{|l|}{ Value } \\
\hline Equal variances assumed & 2.344 & 0.131 & -7.713 & 58 & 0.000 & -4.067 & 0.527 & -5.122 & -3.011 \\
\hline Equal variances not assumed & & & -7.713 & 54.409 & 0.000 & -4.067 & 0.527 & -5.124 & -3.010 \\
\hline
\end{tabular}

\section{Qualitative Phase}

In this phase of the study, the researcher also investigates learners' attitude toward mobile social networking supported writing. Learners' attitudes and perceptions were asked through online semi-structured interviews (see Appendix 1) which provided insightful feedback for the researcher about the amount of learners' satisfaction of participating in the treatment. In doing so, the researcher prepared the verbatim transcriptions of the interviews and then summarized and categorized them thematically. After the researcher analyzed the interview transcripts, an external rater with an M.A. in TEFL, evaluated all of the patterns and themes that the researcher identified from the transcripts in order to prevent influences from analytical biases

Findings were positive where the majority of respondents were satisfied with the using the proposed supplementary strategy parallel to their traditional classes to practice writing collaboratively. Students' perception of their improvement can be seen as a major achievement of this study. All of them strongly believed that it was a productive experience which enabled them to practice what they had learned. They almost could access this writing platform anywhere to engage learning and share expertise and knowledge with each other. The participants acknowledged that they learned from others' mistakes during the writing process and resulted in better writing performance.

One noted that "We learned many things while reading the final and corrected version of the written story. In fact, we learned from our mistakes". Similarly, they enjoyed using the mobile social networking apps as an integral part of their learning activities. In this regard, they explained that:
"It was a lot more fun than working alone"

"It was more interesting that we all were engaged to find a better word or sentence. In other words, we were all thinking together"

"I learned how to work with my friends to have enjoyable learning"

Moreover, many of the respondents agreed that they felt confident using the mobile apps on this course and they felt confident to have another language learning experience like this in the future. They believed that implementing online writing strategies can eliminate their writing deficiencies. Most of them also suggested that a strategy like this can be applied as a regular activity.

Overall motivation with the course was also perceived as positive. More than half of the respondents reported that interacting with their instructor motivated them. They declared that these jigsaw writing activities helped them manifest all their competence in terms of vocabulary and grammar. Nevertheless, all interviewees concurred that the proposed strategy introduced a dynamic environment for group work in which all the participants were trying to do their best in order to create one or more sentences to evolve what the others had written.

It should not be ignored that the process was not an easy task for the entire participants. There were few learners who did not particularly enjoy these tasks, especially during early sessions. In fact, they found this type of projects time-consuming and frustrating because of time delay to send posts. Although it was hard for some of the students to adapt themselves at initial sessions, they admitted that they enjoyed the instruction especially when the teacher provided them some 
clues to develop their ideas. One of them mentioned: "When the teacher told that describe the man in terms of personality and appearance, I could write.I did not really know how I continue the story". Another learner quoted: "We received ideas from prior sentences.I could not predict what they wanted to write".

Some others commented that:

"Writing correctly was difficult". "I was concentrated on giving good direction to the story. So, sometimes I made terrible mistakes".

"I always was thinking of developing the idea rather than finding mistakes.but I learned a lot from my peers' mistakes. Sometimes I corrected my sentences".

"Well, it was really difficult to write correctly. I checked my sentences several times before posting to the group".

About providing feedback some of them commented:

"It is easier to find others mistakes"

"I was worried that my friend might get angry if I correct her.so I tried to ignore some of her mistakes.the teacher could correct her.why me?"

"It was difficult to correct their peers mistakes"

"We tried to shape better sentences. In order to do so, we replaced a word with another.or suggested a different sentence to give better direction to the story".

The researcher received a number of complaints, too.

Few participants were dissatisfied with two or three topics presented. They argued that they did not have enough information about those topics.

One commented that: "It is difficult to criticize your friends.I did not like to modify what they had written".

Some pinpointed the problem of unequal participation of members. Inactive learners created sentences which were much shorter than others and were simpler in terms of grammatical complexity.

Overall, the following themes emerged from the data:

- Positive attitude of learners' toward the influence of mobile social networking on their writing proficiency

- Merits and demerits of implementing such supplementary strategies in parallel to traditional classes;

- Enjoyable and stress-free experiences in such collaborative environment;

- Manifestation of their written knowledge in an enjoyable and friendly learning environment;

- Close interpersonal relationship/positive interdependence.

\section{DISCUSSION \& CONCLUSION}

With regard to the first goal, students were supposed to join a group in telegram application in order to participate in a jigsaw writing activity. They sent their sentences related to predetermined topics to shape a story jointly. The purpose of assessment in this study is to measure an individual's ability to learn from collaboration. To this purpose, the researcher assigned an additional task (Post-test) to each member of the group beyond the group task to find out the extent of knowledge they had gained from others in the collaborative tasks. In this way, each learner' performance was assessed separately.
The statistics indicated that students in the experimental group could outperform their counterparts in the post-test. So, they had a better comprehension of idea development and text management. Therefore, social networking could significantly increase learners' writing ability. That means the only null hypothesis is rejected. This finding is in line with previous studies which have proved the efficacy of online collaborative writing in enhancing grammatical accuracy and other types of writing (Lee, 2010; Eloa \& Oskoz, 2010).

The efficacy of mobile social networking can be explained two-fold: Firstly, it seems that group collaboration to produce a text is closely related to the notion of ZPD. In Ortega's (2009) interpretation, ZPD is a distance between what a student can do in a joint activity that is other-regulated, and what he or she can accomplish alone in an independent activity that is self-regulated. Secondly, the process of such collaborative project can be justified by the notion of scaffolding. It refers to a kind of process that enables a novice to solve a problem or achieve a goal which would be beyond his unassisted efforts (Wood, Bruner, \& Ross, 1976) which is highly encouraged in this type of learning.

According to (Daniels, 2007), "scaffolding has four key features: (1) Meaningful and culturally desirable activity beyond current understanding of learner (2) Assistance...using online diagnosis of the learners' understanding and skill level (3) Support.which may vary in mode as well as in amount (4) the support provided is gradually withdrawn as control of the task is transferred to the learner" (p. 323). As can be seen, all these four characteristics of scaffolding are all provided by the teacher in a social networking environment. Moreover, participants were actively engaged in the collaborative learning environment by sharing their feedback with each other which is of significant importance to scaffolding. Unfortunately, the literature regarding mobile social networking suffers from a dearth of research in this realm and this study can be regarded as a good starting point.

Considering the second goal of the study, an online-semi-structured interview was conducted in order to investigate learners' attitudes toward mobile social networking supported writing. As Bogardus (1931) suggested, “An attitude is a tendency to act toward or against something in the environment which becomes thereby a positive or negative value" (p. 62). The attitudes of the students can be best explained by their performances during the project as well as their answers to the interview questions. The result showed that learners' attitudes toward mobile social networking assisted writing as a supplementary strategy are highly positive. Similarly, Ezza and Bakry (2014) reported that learners held positive attitudes towards the use of such educational technology to support traditional teaching.

This project offers writing-for-learning in which writing is used as a practice tool to help students work with the language they have been studying. Such type of collaborative writing encourages a creative flow that can help students use their imaginations in creating a story. They attempt to exploit their own prerequisite knowledge to make a story. Creativity in learners' writing echoed the cognitive development. Students confirmed that being able to communicate with their 
peers and teacher outside the class is quite precious. In line with Vygotsky's (1978) theory, interaction is crucial in learning. In collaborative writing activity, language is considered as a mediated tool which assists learners to co-construct knowledge and solves problems through interaction.

As Spigelman (2000) mentioned trust and willingness to share authorship are important for collaborative writing. Additionally, collaboration through social networking paves the way for collective scaffolding which is defined by Donato (1994) as a situation in which the speakers are at the same time individually novices and collectively experts to accomplish a complex linguistic problem-solving task. During the treatment, the strong participants helped the weak ones to produce more accurate and better sentences to perform the task. In such situation, learning is facilitated by challenging learners to solve problems rather than delivering direct information (Kadirire, 2009). It is supported by Vygotskey's (1978) socio-cultural theory which suggests that there is a direct connection between interaction and one's psychological and mental development.

It cannot be ignored that learners' positive attitudes toward collaboration in mobile social networking arose their motivation, as well. Overall motivation with the course was also perceived as positive. More than half of the respondents reported that interacting with their instructor motivated them. Moreover, many of the respondents agreed that they felt confident using the mobile apps on this course and they felt confident to have another language learning experience like this in the future. More than half of the respondents reported that interacting with their instructor (as a facilitator) motivated them. It authenticates what Kern (1995) has cited. He believed that CMC environment provides an informal atmosphere which often motivates students to participate more actively. This result also is in line with Brown (2001) who mentioned one of the advantages of collaborative writing is motivation promotion. Increasing Students' active motivation would push them to strive for better performance (Aarts \& McMahon, 2008). That is why Palmer and Goetz (1988) stated that motivational beliefs are important factors that affect self-learning and help learners take responsibilities in learning.

Receiving feedback from both the instructor as well as immediate feedback from the group are important forms of evaluation (Rushatz, 1992). When learners receive feedback on their writing performance, they notice the gaps between what they already know in terms of grammar and vocabulary and what they should achieve. However, in some learners' view, "peer feedback" and "peer reviewing" equates with "criticism". To avoid such result, giving overly general comments should be avoided. Meanwhile, providing feedback entails having a good command of the language. That is why the researcher has chosen learners of intermediate level for incorporating such experiment. Certainly, low proficiency learners have limited linguistic repertoire to provide appropriate feedback. Some studies in this field can prove that feedback can more effectively assist students of intermediate proficiency than with beginning or more advanced students (Carroll, 2001; Lyster \& Ranta, 1997). Furthermore, the findings showed that it encouraged self-assessment and learning from peers while maintaining privacy which, in turn, improved the classroom dynamics which is in the same vein with the study of Gere and Stevens (1985).

This study rests heavily on peer feedback rather than teacher feedback; although, it was believed that in comparison with the teacher feedback, the peer feedback was less effective on improving writing (Connor \& Asenavege, 1994; Zhang, 1985; Vasu, Ling, \& Nimehchisalem, 2016). Studies like Paulus (1999) and Mendoca and Johnson (1994) found peer correction significant in student writing improvement and consider its role as helpful. On the other hand, as they themselves also have to provide feedback to their peers, they learn to critically analyze and revise their own writing (Mendoca \& Johnson, 1994). As Rollinson (2005) stated, "by giving students practice in becoming critical readers, we are at the same time helping them towards becoming more self-reliant writers, who are self-critical and who have the skills to self-edit and revise their writing" (p. 29). This can be a step towards autonomy.

Establishing positive interdependence can be seen as an outcome of this collaborative writing project. As Johnson, Johnson and Holubec (1998) defined: "Positive interdependence is linking students together so one cannot succeed unless all group members succeed" (p. 4). In this way, all members rely on one another to achieve a certain goal. Therefore, such collaborative experience mitigates the sense of competition between learners. It also trains them to be more tolerant and flexible

Integrating social networking apps into learning seems to be one of the most promising ways of using technology to plan desired changes in educational practice. Undoubtedly, the synergy between social networking sites and collaborative learning double the potentials of this proposed strategy. There is ample evidence that collaborative learning works and is valuable to students, educators and policymakers. Therefore, such learning has a potential to establish a radically new paradigm by manipulating traditional design in order to overcome the constraints in EFL contexts as there are fewer opportunities to practice what they have learned which allows learners to notice linguistic gaps and organizational problems in their writing. Consequently, such authentic practice leads to promoting English learning. However, participating in such online collaborative writing requires a good command of English language. So, this supplementary strategy cannot be applicable for beginners. That is why the researcher chose intermediate learners for the treatment.

In order to mitigate deficiencies and getting a better result, teachers who employ technology need to be aware of any technology shortcomings and be proficient in its use. Warschauer (2002) identifies four types of electronic literacies which teachers should possess: Computer literacy (i.e. comfort and fluency in keyboarding and using computers); information literacy (i.e. the ability to find and critically evaluate online information); multimedia literacy (i.e. images and sounds); and computer-mediated communication literacy (i.e. knowledge of the pragmatics of individual and group online interaction). Being proficient in employing 
these technologies can result in more successful teaching process in recent years. Therefore, there is a need for pre or in-service education programs to acquire these technology skills for establishing innovative pedagogy in order to modify their monotonous teaching method. Instead of asking "Why technology-supported learning" we might ask "How we can use these technologies to make learning more efficient".

\section{REFERENCES}

Aarts, B., \& McMahon, A. (Eds.). (2008). The Handbook of English linguistics. Malden, MA: John Wiley \& Sons.

Alexander M. (2008), Good writing leads to good testing. https://www.stickyminds.com/article/good-writingleads good-testing

Beck, E. (1993). A survey of experiences of collaborative writing. In Computer supported collaborative writing, ed. M. Sharples, 9-28. London: Springer-Verlag.

Bogardus, E. S. (1931). Fundamentals of Social Psychology. New York: Century.

Brown, H. D. (2001). Teaching by principles: an interactive approach to language pedagogy. White Plains, NY: Longman.

Byrne, D. (1979). Teaching writing skills. London: Longman House.

Carroll, S. E. (2001). Input and evidence: The raw material of second language acquisition (Vol. 25). Amsterdam: John Benjamins Publishing Company.

Colomb, G.G., \& Simutis, J.A. (1996). Visible conversation and academic inquiry: CMC in a culturally diverse classroom. In S. Herring (Ed.), Computer-mediated communication: Linguistic, social and cross-cultural perspectives (pp. 203-222). Amsterdam: John Benjamins.

Connor, U. \& Asenavage, K. (1994). Peer response groups in ESL writing classes: How much impact on revision? Journal of Second Language Writing, 3(3), 257-276.

Curcher. M. (2009). A Case Study Examining the Implementation of Social Networking Technologies to Enhance Student Learning for Students Learning in a Second Language. http://www.aln.org/publications/jaln/v5n2/ pdf/v5n2_brown.pdf (Accessed 25 November 2012).

Dale, H. (1997). Co-authoring in the classroom: Creating an environment for effective collaboration. Urbana, IL: The National Council of Teachers of English.

Daniels, H. (2007). Pedagogy. In H. Daniels, M. Cole \& J. V. Wertsch (Eds.), The Cambridge companion to Vygotsky (pp. 307-331). Cambridge: Cambridge University Press.

Donato, R. (1994). Collective scaffolding in second language learning. In J. P. Lantolf \& G. Appel (Eds.), Vygotskian approaches to second language learning, (pp. 33-56). Norwood, NJ: Ablex Publishing Corporation.

Dornyei, Z. (2001). Motivational Strategies in the Language Classroom. Cambridge: Cambridge University Press.

Dornyei, Z. (2001). Teaching and researching motivation. London: Longman.

Ede, L., \& Lunsford, A. (1990). Singular texts/plural authors: Perspectives on collaborative writing. Carbondale, IL: Southern Illinois Press.
Elola, I., \& Oskoz, A. (2010). Collaborative writing: Fostering foreign language and writing conventions development. Language Learning \& Technology, 14(3), 51-71.

Ezza, S., \& Bakry, S. A. (2014). Technology-Enhanced Instruction in a Saudi EFL Classroom. Arab World English Journal. 8(12), 55-66.

Faghih, E., \& Rahimpour, S. (2009). Contrastive rhetoric of English and Persian written texts: Metadiscourse in applied linguistics research articles. Rice Working Papers in Linguistics, 1, 92-107.

Fahim, M., Miri, M., \& Najafi, Y. (2014). Contributory role of collaborative assessment in improving critical thinking and writing. International Journal of Applied Linguistics \& English Literature, 3(1), 1-11.

Gere, A.R., \& Stevens, R.S. (1985). The language of writing groups: How oral response shapes revision. In S. W. Freedman (Ed.), The acquisition of written language: Response and revision (pp. 85-105). Norwood, NJ: Ablex.

Gokhale, A. A. (1995). Collaborative learning enhances critical thinking. Journal of Technology Education, 7(1), 22-30.

Hatch, E. \& Farhady, H. (1982) Research Design and Statistics for Applied Linguistics, Newbury House.

Hatch, E. M. \& Lazaraton, A. (1991). The research manual: design and statistics for applied linguistics. New York: Newbury House.

Johnson, D., Johnson, R. \& Holubec, E. (1998). Cooperation in the classroom. Boston: Allyn and Bacon.

Johnson, D. W., \& Johnson, R. T. (2004). Cooperation and the use of technology. In D. H. Johanssen. ( $2^{\text {nd }}$ ed.), Handbook of research on educational communications and technology (pp. 785-811). Mahwah, NJ: Lawrence Erlbaum Associates.

Johnson, D. W., Johnson, R. T., \& Smith, K. A. (1991). Cooperative learning: Increasing college faculty instructional productivity. Washington, D. C.: The George Washington University, School of Education and $\mathrm{Hu}-$ man Development.

Johnson, D. W., Johnson, R.T., \& Smith, K. A. (2007). The state of cooperative learning in postsecondary and professional settings. Educational Psychology Review, 19(1), 15-29.

Kadirire, J. (2009). Mobile Learning DeMystified. In R. Guy (Ed.), The Evolution of Mobile Teaching and Learning (pp. 15-56). Santa Rosa, California: Informing Science Press.

Kern, R. (1995). Restructuring classroom interaction with networked computers: Effects on quality and characteristics of language production. Modern Language Journal, 79(4), 457-476.

Kessler, G. (2009). Student initiated attention to form in autonomous wiki based collaborative writing. Language Learning \& Technology, 13(1), 79-95.

Kessler, G., Bikowski, D., \& Boggs, J. (2012). Collaborative writing among second language learners in academic web-based projects. Language Learning \& Technology, 16(1), 91-109. 
Khabiri, M., \& Tonekaboni, F. (2009). How to Boost Academic Essay Writing: A Choice between Process and Product Writing. Journal of Teaching.

Krashen, S.D. (1985). The Input Hypothesis: Issues and Implications. London: Longman.

Kumar, R. (2005). Research methodology: A step-by-step guide for beginners. London: Sage Publication.

Lee, H. (2010). Smart phone based Chinese education application project and production experiment. Unpublished master's thesis. Ewha Woman's University, Seoul.

Lee, L. (2002). Enhancing learners' communication skills through synchronous electronic interaction and task-based instruction. Foreign Language Annuals, 35(1), 16-24.

Lee, L. (2010). Exploring wiki-mediated collaborative writing: A case-study in an elementary Spanish course. $C A L$ ICO Journal, 27(2), 260-276.

LeFevre, K. B. (1987). Invention as a social act. Carbondale: Southern Illinois University.

Louth, R., McAllister, C., \& McAllister, H. A. (1993). The effects of collaborative writing techniques on freshman writing and attitudes. Journal of Experimental Education, 61(3), 215-224.

Lyster, R. \& Ranta, L. (1997). Corrective feedback and learner uptake: Negotiation of form in communicative classrooms. Studies in Second Language Acquisition, 19(1), 37-66.

Masoodian, M., \& Luz, S. (2001). COMAP: A content mapper for audio-mediated collaborative writing. Usability Evaluation and Interface Design, 1, 208-212.

Mellati, M., \& Khademi, M. (2014). Peer evaluation in CMC learning environment and writing skill. International Journal of Applied Linguistics \& English Literature. 3(5), 220-228.

Mendonça, C. \& Johnson, K. E. (1994). Peer review negotiations: Revision activities in ESL writing instruction. TESOL Quarterly, 28(4), 745-769.

Nguyen, L. V. (2008). Computer mediated communication and foreign language education: Pedagogical features. International Journal of Instructional Technology and Distance Learning, 5(12), 23-44. Retrieved from http:// www.itdl.org/Journal/Dec_08/article02.htm

Nystrand, M., \& Brandt, D. (1989). Response to writing as a context for learning to write. In C. M. Anson (Ed.), Writing and response: Theory, practice, and research (pp.209-230). Urbana, IL: National Council of Teachers of English.

O’Sullivan, D., Mulligan, D., \& Dooley. L. (2007). Collaborative information system for university-based research institutes. International Journal of Innovation and Learning, 4(3), 308-322.

Ortega, L. (2009). Understanding second language acquisition. London, UK: Hodder Education.

Palincsar, A. S. (1987). Collaborating for collaborative learning of text comprehension. Paper presented at the annual meeting of the American Educational Research Association, Washington, D.C.

Palmer, D. J., \& Goetz, E. T. (1988). Selection and use of study strategies: The Role of the studier's beliefs about self and strategies. In C. E. Weinstein et al. (Eds.), Learning and study strategies: Issues in assessment, instruction, and evaluation (pp. 77-100). San Diego, CA: Academic Press Inc.

Parker, S. (1993). The Craft of Writing. London: Paul Chapman Publishing.

Paulus, T. M. (1999). The effect of peer and teacher feedback on student writing. Journal of Second Language Writing, 8(3), 265-289.

Pellettieri, J. (1999). Negotiation in cyberspace: The role of chatting in the development of grammatical competence. In. M. Warschauer \& R. Kern (Eds.), Network-based language teaching: Concepts and practice (pp. 59-86). Cambridge: Cambridge University Press.

Pennington, M. C. (1991). Positive and negative potentials of word processing for ESL writers. System, 19(3), 267-275.

Rahimi, M., \& Yadollahi, S. (2010). Computer anxiety and ICT integration in English classes among Iranian EFL teachers. Procedia Computer Science, 3, 203-209 Retreieved from http://dx.doi.org/10.1016/j. procs.2010.12.034

Raimes, A. (1983). Techniques in teaching writing. New York: Oxford University Press.

Rice, R. P., \& Huguley, J. T. J. R. (1994). Describing collaborative forms: A profile of the team writing process. IEEE Transactions on Professional Communication, 37(3), 163-170.

Richards, J.C. \& Renandya, W.A. (eds.). (2002). Methodology in Language Teaching; AN Anthology of Current Practice. Cambridge: Cambridge University Press.

Rollinson, P. (2005). Using peer feedback in the ESL writing class. ELT Journal, 59 (1), 23-30. Retrieved from http:// eltj.oxfordjournals.org/content/vol59/issue1/index.dtl

Rushatz, T. A. (1992). Cooperative learning: An examination of attitudes toward cooperative learning and its effectiveness. B.S. Thesis. State College, PA: The Pennsylvania State University.

Santangelo, T. \& Olinghouse, N. G. (2009). Effective writing instruction for students who have writing difficu ties. Focus on Exceptional Children, 42(4), 1-20.

Saunders, W. M. (1989). Collaborative writing tasks and peer interaction. International Journal of Educational Research, 13(1), 101-112.

Speck, B. W., Johnson, T. R., Dice, C. P., \& Heaton, L. B. (1999). Collaborative Writing: An Annotated Bibliography. Westport, CT: Greenwood Press.

Spigelman, C. (2000). Across property lines: Textual ownership in writing groups. Carbondale: Southern Illinois University Press.

Storch, N. (2005). Collaborative writing: Product, process, and students' reflections. Journal of Second Language Writing, 14, 153-173.

Trimbur, J. (1985). Collaborative learning and teaching writing. In B. W. McClelland \& T. R. Donovan (Eds.), Perspectives on research and scholarship in composition (pp. 87-109). New York: Modern Language Association.

Uysal, H. H. (2010). A critical review of the IELTS writing test. ELT Journal, 64(3), 314-320. 
Vasu, K., Ling, C. H., \& Nimehchisalem, V. (2016). Malaysian tertiary level ESL students' perceptions toward teacher feedback, peer feedback and self-assessment in their writing. International Journal of Applied Linguistics \& English Literature, 5(5), 158-170.

Vygotsky, L. S. (1978). Mind in Society: The development of higher psychological processes. Cambridge, MA: Harvard University Press.

Warschauer, M. (1997). Computer-mediated collaborative learning: Theory and practice. The Modern Language Journal, 81(4), 470-481.

Warschauer, M. (1999). Electronic literacies: Language, culture, and power in online education. Mahwah, NJ: Lawrence Erlbaum Associates.

Warschauer, M. (2002). A developmental perspective on technology in language education. TESOL Quarterly, 36 (3), 453- 475.
Warschauer, M., Turbee, L., \& Roberts, B. (1996). Computer learning networks and student empowerment. System, 24(1), 1-14.

Webb, N. M. (1989). Peer interaction and learning in small groups. International Journal of Educational Research, 13, 21-39.

Wells, G., \& Chang-Wells, G. L. (1992). Constructing knoruledge togethpr. Portsmouth, NH: Heinemann.

Wood, D., Bruner, J. S., \& Ross, G. (1976). The role of tutoring in problem solving. Journal of Child Psychology \& Psychiatry \& Allied Disciplines, 17(2), 89-100.

Zhang, S. (1985). The differential effects of sources of corrective feedback on ESL writing proficienc. University of Hawaii at Manoa: Department of English as a second language.

\section{APPENDIX}

\section{Appendix 1: Semi-structured Interview Questions}

\section{Dear Students,}

Thank you for participating in this study.

Your precise answers based on your views, perceptions, and experience you had during these twelve sessions of treatment would help the researcher to better understanding the effectiveness of mobile social networking as a supplementary strategy. In order to elicit more reliable findings, you are strongly asked to answer the questions frankly. Your answers will be merely used for finding an adequate answer for one of the research questions of the study and will have no effect on your grades. The researcher is looking forward to hearing your voice files

1. Did you feel this strategy helped you to improve your writing?

2. What were the positive aspects of such experience?

3. What were the negative aspects of such experience?

4. How do you like your friends' feedback?

5. Would you like to do similar collaborative writing activities/tasks in the future? 